* Faculty of Economics, University of Belgrade

\title{
Integration of Government Bond Market in the Euro Area and Monetary Policy
}

\begin{abstract}
This paper combines analysis of evolution in euro area government bond market integration and interference of European Central Bank with functioning of respective market recently. Since the introduction of euro, government bond yields converged in the euro area, bonds of different countries have become close substitutes in the perception of investors, and overall integration of the market was rather high. At the end of 2008, dramatic shift occurred and ever since disintegrative forces were set in motion. The paper presents the following measures of integration of the government bond markets: yield spreads, dispersion in yield spreads and beta coefficient. All three measures suggest unprecedented market disintegration as of 2010. The paper highlighted relevance of sovereign bond market for the smooth functioning of the monetary policy transmission mechanism in a monetary union context. Three ECB's programmes aimed at sovereign debt crisis resolution were analysed in details. They proved successful in lowering peripheral countries' yields and spreads, and calming the markets. If one takes central bank function of the lender of last resort for banks, then these programmes may be viewed as the "buyer of last resort" device for government bonds. Although warranted by exceptional circumstances and need for swift response, a due caution should be paid to these programmes since they pose certain challenges for conduct of monetary policy and might even have unintended consequences.
\end{abstract}

Keywords: sovereign debt, bond markets integration, crisis, yield spread, central bank asset purchases

JEL Code: E52, E58, G12, F36 


\section{Introduction}

The government bond market is the bedrock of modern securities markets as a whole. Government bonds with its market serve several very important functions. At the fundamental level, issuing government securities is instrumental in resolving problems such as temporary illiquidity, budget deficit or need to roll over outstanding debt that governments could encounter. Interest rate on government bonds serves as an approximation of risk-free interest rate which is used in widely accepted standard asset pricing models for the purpose of determining the return on equities, non-government bonds and other financial assets. It is a bottom-line interest rate level for non-financial corporations incorporated in one country, so they cannot enjoy more favourable funding terms when financing their business activities. In terms of volume of outstanding government securities, they dominate over other securities in the financial markets. Its market is, not least very large, but usually highly liquid which improves the breadth and depth of financial markets and its overall functioning. Government bonds are very often reused in the market in the sense that they serve as collateral in a vast number of regular transactions, both arranged among private entities or between private and public entities. Central banks most often pursue their open market operations solely on the basis of government securities.

Government securities market in Europe has undergone a period of dynamic development and profound changes in the past fifteen years. Introduction of euro in 1999 was a milestone in this regard. The single currency, in which all new issues of government securities of euro area countries became denominated, has eliminated one prominent factor of segregation among local government securities markets - exchange rate risk. The euro set the ground for establishing truly integrated government bonds markets where supply and demand for these prime securities would interact in one common place. It posed new challenges ahead of individual euro area governments. Previously, they got used to predominant position in the local financial markets, a quasi-monopoly situation, and prime status of their securities. In new circumstances, they needed to compete with other governments for the same, although expanded, pool of funding. New competitive environment provided impetus for governments to change features of their securities, together with issuance practices, so as to render them more appealing to prospective investors. Otherwise, governments would have very likely encountered problems in placement of their securities. The structure of investors in government securities changed as well, with more weight attributing to foreign investors, primarily from the euro area, on the account of domestic ones. Investors started to take the euro area-wide perspective instead of national ones. In order to facilitate the euro area-wide trading in government securities, struc- 
tured trading platforms emerged. In sum, these developments have contributed to a considerable rise in the level of development of the government bond market from 2000 onwards.

This paper combines the analysis of evolution in the euro area government bond market integration and the recent interference of the European Central Bank (ECB) with its functioning. It is structured as follows: section 2 reports tremendous progress in government bond market integration seen in the years preceding the crisis. A two stage crisis, the financial crisis in the first round and the sovereign crisis in the second round hit the government bond market hard and with devastating effects. Section 3 describes their impact on the level of market integration. Conceptual and theoretical arguments explaining the relevance of the government bond market for monetary policy are exhibited in Section 4 . The ECB's modalities of intervention in government bond market in the wake of different phases of the unprecedented crisis with appraisal of their success are presented in Section 5. Section 6 lays out the conclusion.

\section{Developments in the government bond market in the euro area in the period 2000-2008}

Santillan, Bayle \& Thygesen (2000) summarized the main changes in sovereign issuing practices since the introduction of euro: a.) issue sizes have become bigger with minimum value per issue set at 5 billion euros; b.) governments promoted benchmark issues so as to ensure sufficient liquidity, especially when the total amount of sovereign debt is too small to ensure liquidity along the whole yield curve; c.) market transparency has improved with pre-announced auction calendars becoming standard; d.) increased use of primary dealers in order to secure a smooth and diversified placement of sovereign debt; e.) enhanced secondary market liquidity with shift in trading towards using new liquidity enhancing technologies and trading systems such as EuroMTS and f.) innovations in the menu of bonds offered carried out with the intention of servicing investors needs in particular market niches.

Data referring to the structure and characteristics of local government bonds in the EU countries is displayed in Table 1. 
Table 1: The characteristics of the government bond issues in the EU Member States

\begin{tabular}{|c|c|c|c|c|c|}
\hline & \multicolumn{3}{|c|}{ Type of coupon rate (in \%) } & \multicolumn{2}{|c|}{ Maturity (in years) } \\
\hline & Fixed & Floating & Index-linked & Maturity range & Benchmark maturity \\
\hline Austria & 99 & 1 & & Not more than 50 & 5 and 10 \\
\hline Belgium & 99 & 1 & & $2-30$ & 5,10 and 30 \\
\hline Denmark & 100 & & & $2-10$ & 2,5 and 10 \\
\hline Finland & 100 & & & $2-10$ & $3,4,5,7,8$ and 10 \\
\hline France & 94,5 & 4 & 1,5 & $2-30$ & $2,5,10$ and 30 \\
\hline Germany & 77,4 & 8,5 & & $2-30$ & 2,5 and 10 \\
\hline Greece & 64 & 36 & & $2-20$ & $3,5,10$ and 20 \\
\hline Ireland & 100 & & & $2-15$ & $2,5,10$ and 15 \\
\hline Italy & 74 & 26 & & $3,5,10,30$ & $3,5,10$ and 30 \\
\hline Luxemburg & 100 & & & 10 & 10 \\
\hline Netherlands & 97,4 & 2,6 & & $3-30$ & 3,10 and 30 \\
\hline Portugal & 87,3 & 12,7 & & Not more than 30 & 5 and 10 \\
\hline Spain & 100 & & & $3-30$ & $3,5,10,15$ and 30 \\
\hline Sweden & 86 & 0 & 14 & $2-14$ & $2-14$ \\
\hline United Kingdom & 75 & 1 & 23 & $5-30$ & 5,10 and 30 \\
\hline
\end{tabular}

Source: Economic and Financial Committee (2000)

If one takes data from Table 1 as the initial pattern of local government bonds' features, all changes in the subsequent years acknowledge progress in the development of the market. For instance, France was the single euro area country that had issued inflation linked bonds before the introduction of euro. In order to provide competitive bonds in the market, Italy, Greece, Austria and Germany issued these bonds in timely manner after the emergence of euro. Furthermore, inflation indexed bonds were initially indexed to national price indices, but some issues emerged that had been indexed to a European price index. Also, Spain and France have issued constant maturity bonds whose coupon rate is periodically reset to the prevailing ten-year bond yield and which account for innovation in the market. Interestingly, the Bank of England has started to issue euro-denominated Treasury bills. As regards maturity, governments generally opted for issuing long-term securities rather than short-term one, with securities with a maturity of ten years or more playing the major role in the long-term segment.

Table 2 depicts the size of individual euro area countries' government securities markets coupled with the share of euro-denominated public debt securities in total public debt. 
Table 2: Outstanding nominal amounts of public debt securities

\begin{tabular}{lcccc|c|c|c|c}
\hline & $\begin{array}{c}\text { Outstanding amount of public debt } \\
\text { securities (in billions } € \text { ) }\end{array}$ & \multicolumn{3}{c}{$\begin{array}{c}\text { Share of public debt securities in } \\
\text { total public debt (in \%) }\end{array}$} \\
\hline & 2000 & 2002 & 2004 & 2006 & 2000 & 2002 & 2004 & 2006 \\
\hline Austria & 101,5 & 110,2 & 114,4 & 128,9 & 73,3 & 75,7 & 76,0 & 79,5 \\
\hline Belgium & 242,8 & 256,0 & 254,2 & 256,3 & 89,8 & 92,7 & 93,2 & 92,0 \\
\hline Germany & 779,9 & 867,3 & 1006,6 & 1123,1 & 63,8 & 67,1 & 69,4 & 70,5 \\
\hline Spain & 303,0 & 319,0 & 330,9 & 336,9 & 81,2 & 83,3 & 85,2 & 85,9 \\
\hline Finland & 53,9 & 51,0 & 54,8 & 53,4 & 93,0 & 85,9 & 81,5 & 80,1 \\
\hline France & 643,4 & 743,2 & 891,9 & 950,1 & 79,8 & 82,4 & 83,4 & 81,1 \\
\hline Greece & 11,4 & 123,3 & 158,8 & 158,5 & 8,2 & 77,6 & 86,9 & 90,9 \\
\hline Ireland & 21,8 & 22,3 & 31,3 & 31,2 & 55,2 & 53,3 & 71,5 & 65,2 \\
\hline Italy & 1064,9 & 1094,8 & 1144,2 & 1232,8 & 82,1 & 80,1 & 79,4 & 78,7 \\
\hline Luxemburg & 0,7 & 0,6 & 0,4 & 0,1 & 56,1 & 38,1 & 22,0 & 3,3 \\
\hdashline Netherlands & 177,6 & 189,2 & 215,4 & 211,8 & 79,0 & 80,5 & 83,8 & 76,7 \\
\hline Portugal & 47,2 & 59,8 & 72,9 & 89,8 & 76,6 & 79,6 & 87,0 & 88,8 \\
\hline Euro area & 3448,1 & 3836,9 & 4275,8 & 4599,9 & 74,5 & 77,7 & 79,0 & 78,5 \\
\hline
\end{tabular}

Source: European Central Bank (2007)

The absolute size of public debt securities market closely follows relative size of national economies, but not entirely in a consistent order. The largest individual market for government bonds is that of Italy although its national economy ranks third in euro area. Italian, German, and French bonds together constitute over two thirds of the public debt securities market in the euro area. At the start of decade, the market for Italian public debt securities alone reached over the limit of 1 trillion euros in size, followed by the German market since 2004 onwards. One might observe a modest proportion of public debt securities in total public debt for Germany, which partly accounts for the shortfall in size of its market for government securities. Nevertheless, the German market was catching up with Italian market given that its average annual growth rate in the period 2000-2006 was $6.3 \%$, compared to the respective Italian growth rate of only $2.5 \%$. An outstanding growth in the period under consideration has been attributed to the Portuguese market with an average growth rate of $11.3 \%$.

An important integrating factor for the government bond markets in the euro area has been convergence in creditworthiness of member countries. Credit risk of investments in securities encompasses the risk of defaulting on bond payments and the risk of issuer being downgraded before bond maturity dates. In normal circumstances, the latter kind of credit risk in government bond markets is more 
pronounced, while the former is rather negligible. A lower credit rating implies a higher risk premium, which translates into a rise in discount rate for bonds, a fall in their market value, and capital losses for their holders. Table 3 displays changes in credit rating for the euro area countries in the period from the start of the previous decade up to the global financial crisis outbreak.

Table 3: Developments of credit rating rankings for euro area countries

\begin{tabular}{|c|c|c|c|c|c|c|c|c|c|}
\hline & 2000 & 2001 & 2002 & 2003 & 2004 & 2005 & 2006 & 2007 & 2008 \\
\hline \multirow{2}{*}{ Austria } & AAA & AAA & AAA & AAA & AAA & AAA & AAA & AAA & AAA \\
\hline & Aaa & Aaa & Aaa & Aaa & Aaa & Aaa & Aaa & Aaa & Aaa \\
\hline \multirow{2}{*}{ Belgium } & AA- & AA- & AA & AA & $A A$ & AAt & AA+ & $A A+$ & AAt \\
\hline & Aal & Aa1 & Aa1 & Aa1 & Aal & Aal & Aa1 & Aa1 & Aa1 \\
\hline \multirow{2}{*}{ Germany } & AAA & AAA & AAA & AAA & AAA & AAA & AAA & AAA & AAA \\
\hline & Aaa & Aaa & Aaa & Aaa & Aaa & Aaa & Aaa & Aaa & Aaa \\
\hline \multirow{2}{*}{ Spain } & $A A+$ & AAt & AA+ & AAA & AAA & AAA & AAA & AAA & AAA \\
\hline & $\mathrm{Aa} 2$ & Aaa & Aaa & Aaa & Aaa & Aaa & Aaa & Aaa & Aaa \\
\hline \multirow{2}{*}{ Finland } & AAA & AAA & AAA & AAA & AAA & AAA & AAA & AAA & AAA \\
\hline & Aaa & Aaa & Aaa & Aaa & Aaa & Aaa & Aaa & Aaa & Aaa \\
\hline \multirow{2}{*}{ France } & AAA & AAA & AAA & AAA & AAA & AAA & AAA & AAA & AAA \\
\hline & Aaa & Aaa & Aaa & Aaa & Aaa & Aaa & Aaa & Aaa & Aaa \\
\hline \multirow{2}{*}{ Greece } & A- & A & A & A+ & A & A & A & $A$ & A \\
\hline & $\mathrm{A} 2$ & A2 & $\mathrm{A} 1$ & $\mathrm{~A} 1$ & A1 & A1 & A1 & $\mathrm{A} 1$ & A1 \\
\hline \multirow{2}{*}{ Ireland } & AAA & AAA & AAA & AAA & AAA & AAA & AAA & AAA & AAA \\
\hline & Aaa & Aaa & Aaa & Aaa & Aaa & Aaa & Aaa & Aaа & Aaa \\
\hline \multirow{2}{*}{ Italy } & AA- & AA- & AA & AA & AA & AA & $A A-$ & AA- & AA- \\
\hline & $\mathrm{Aa3}$ & Aa3 & $\mathrm{Aa} 2$ & $\mathrm{Aa} 2$ & $\mathrm{Aa} 2$ & $\mathrm{Aa} 2$ & $\mathrm{Aa} 2$ & $\mathrm{Aa} 2$ & $\mathrm{Aa} 2$ \\
\hline \multirow{2}{*}{ Cyprus } & At & At & A+ & A+ & A+ & A+ & A+ & $A A-$ & $A A-$ \\
\hline & $A 2$ & A2 & A2 & $A 2$ & A2 & $A 2$ & $\mathrm{~A} 2$ & A1 & $\mathrm{Aa3}$ \\
\hline \multirow{2}{*}{ Malta } & A & A & A & A & A & A & A & At & $\mathrm{A}+$ \\
\hline & A3 & A3 & A3 & A3 & A3 & A3 & A3 & $\mathrm{A} 2$ & A1 \\
\hline \multirow{2}{*}{ Netherlands } & AAA & AAA & AAA & AAA & AAA & AAA & AAA & AAA & AAA \\
\hline & Aaa & Aaa & Aaa & Aaa & Aaa & Aaa & Aaa & Aaa & Aaa \\
\hline \multirow{2}{*}{ Portugal } & AA & $\mathrm{AA}$ & AA & AA & AA & AA & AA & AA & AA \\
\hline & $\mathrm{Aa} 2$ & $\mathrm{Aa} 2$ & $\mathrm{Aa} 2$ & $\mathrm{Aa} 2$ & $\mathrm{Aa} 2$ & $\mathrm{Aa} 2$ & $\mathrm{Aa} 2$ & $\mathrm{Aa} 2$ & $\mathrm{Aa} 2$ \\
\hline \multirow{2}{*}{ Slovenia } & A & A & A & A+ & AA- & AA- & AA & AA & AA \\
\hline & $\mathrm{A} 2$ & A2 & $\mathrm{Aa3}$ & $\mathrm{Aa3}$ & $\mathrm{Aa} 3$ & $\mathrm{Aa} 3$ & $\mathrm{Aa} 2$ & $\mathrm{Aa} 2$ & $\mathrm{Aa} 2$ \\
\hline
\end{tabular}

Source: Fitch and Moody's 
One can observe that six euro area countries have enjoyed top-notch rating in continuity from the start of the period analysed, with Spain joining them in 2003. The influence of accession to the euro area on a country's credit rating might be observed on the sample of three countries - Slovenia, Cyprus, and Malta. Moody's rating agency was raising credit rating for one notch to Cyprus and Malta in every year starting from 2006, as they regularly approached due date for the introduction of euro. Fitch agency was more conservative when assigning rating categories to all three countries and decided to allow them upgrade in credit rating for exactly one notch in the year that preceded the effective introduction of euro.

Credit rating data from Table 3 suggests that the euro area countries, especially those that initially introduced euro, have exceptionally high credit rating so one should plausibly expect their bonds' yields to maturity to be very close to each other. In the most general level, direct comparison of bond yields may be employed as a rough indicator of integration of government bond markets in the euro area. However, a more cautious approach is based on employing yield spreads. It is defined as the difference between the respective bond yield and yield on the benchmark bond. The notion is that yield on the benchmark bond approximates the yield that would prevail in the perfectly integrated market. German government bonds are most often used as benchmark bonds given that their credit risk is virtually non-existent, while their liquidity is very high due to developed derivatives market linked to them. On the same ground, French bonds might be used as well. Figure 1 exhibits crosscountry standard deviation of government bond yield spreads for bonds with maturities of two, five, and ten years in the pre-crisis period.

The lower the dispersion in yield spreads, the market for government bonds is deemed more integrated. The impressive progress in the level of market integration stems

Figure 1: Cross-country standard deviation in government bond yield spreads (vis-à-vis German rate)

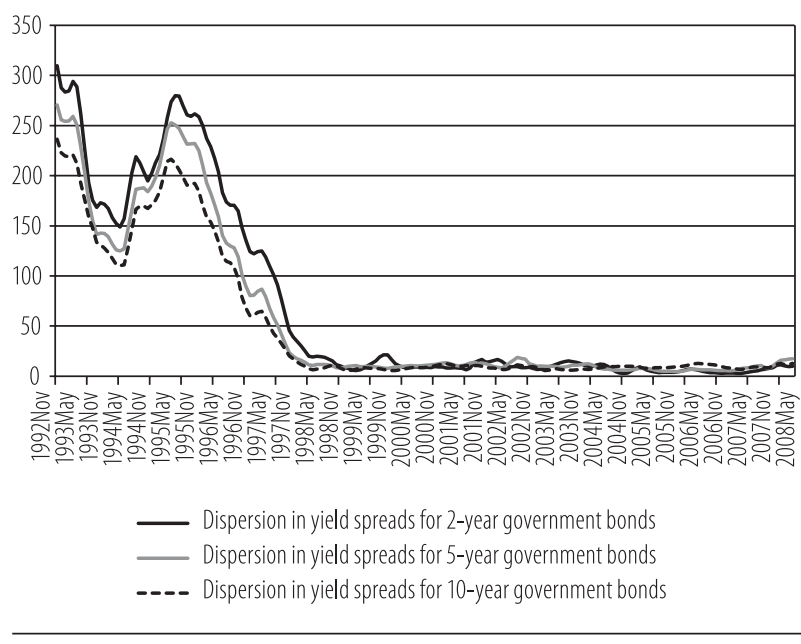

Source: Author's calculations 
from Figure 1 for all three maturity segments. While in the first half of 1990s dispersions had fluctuated around 200 basis points, in the second half they decreased substantially and from 1998 until 2008 they were kept below the level of 10 basis points up, with periods where they were as low as 2-3 basis points. This metric is a strong evidence of convergence of government bond yields in the euro area which may be attributed primarily to the convergence in underlying fundamentals.

\section{Developments in government bond market in euro area after the onset of financial crisis}

A positive impression about development of government bond markets and its advancement in terms of the level of market integration has been disrupted by critical occurrences in the global financial market at the end of 2008. Unlike global financial crises in 1990s that had been triggered by financial collapse of the Asian emerging economies or Russia, the subprime mortgage market in the USA stood at the epicentre of the newly emerging crisis. Due to the networking feature of global financial flows and interconnectedness of national economies, the crisis spilled over swiftly to the rest of the world and hit the real sector as well.

The financial and economic crisis has negatively impacted fiscal developments in all European countries. Contraction of economic activity has pushed down the level of government revenues. On the opposite side, government expenditures were rising rapidly. The rise was associated with national economic stimulus packages aimed at recovery of economic activity and rescue packages for the financial sector. For instance, measures introduced in order to safeguard stability of the banking sector comprised: a.) capital injections - executed as acquisition of preference shares or hybrid instruments, b.) bank assets support schemes - in the form of asset removal programs or asset insurance schemes and c.) government guarantees on bank liabilities - such as increase in the size of customer deposits covered by deposit insurance scheme.

The outcome of these developments were rising budget deficits and deterioration of indicators of government debt burden - debt to GDP ratio. Ireland is a typical example of emerging crisis in public finances. Its budget surplus in the pre-crisis period turned unstoppably into growing deficit which culminated in 2010 when it amounted to $-32.4 \%$. As a consequence, its debt to GDP ratio climbed from $25 \%$ to $100 \%$. Greece, who had an imbalanced budget and a deficit of structural nature even before the crisis onset has reported the largest debt to GDP ratio of $160 \%$. Portugal was also hardly affected by the crisis. These three countries asked 
for international financial support in order to prevent default on their accrued liabilities, including, inter alia those from government bonds ${ }^{1}$.

Deteriorated fiscal situation in virtually all euro area countries, but with different magnitude, brought about divergent developments in the government bond market. Interestingly, average yield on bonds with 10-year maturity has not considerably changed in the turbulent times that occurred after 2008. Nevertheless, dispersion of government bond yields reacted in an expected manner, exhibiting a sharp increase. Figure 2 plots developments in average yield and dispersion measures.

\section{Figure 2: Dispersion of government bond yields and evolution of average yield}

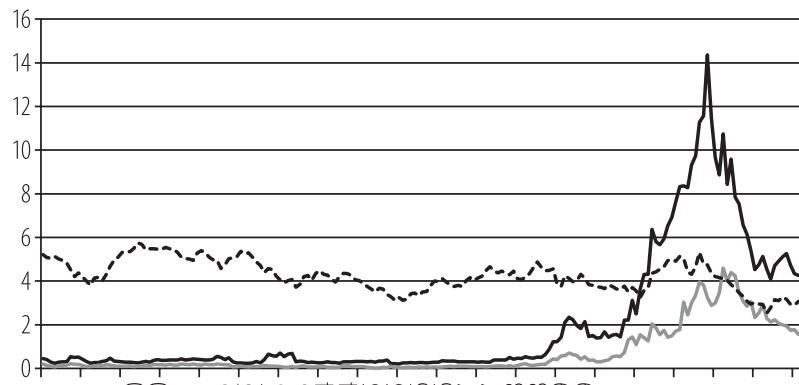

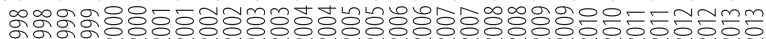

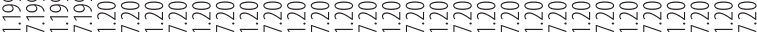

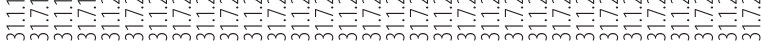

- Range

- Interquartile range

---- Average yield for government bonds with ten year maturity in euro area

Source: Author's calculations

Looking at Figure 2 in more details, one can observe low range and interquartile range up until the end of 2008. This complies with the assessment made in previous section of high market integration. In 2009, the range moderately increased and in the following year it surged, finally reaching the unprecedented level in 2011, the level that was above those observed in the first half of 1990s. In January 2012, it stood at the historic high of 14.36 percentage points. The interquartile range also exhibited a strong upward trend in the respective period, although it did not surpass its record high evidenced in the 1990s. Gauging the state of integration in the government bond market solely on the account of dispersion

1 The first country to sign a financial arrangement with the IMF and the EU was Greece, in May 2010. Ireland followed and signed the agreement in November 2010, while Portugal negotiated the agreement in April 2011. The terms and conditions of these agreements complied entirely with those the IMF requires from its member countries when granting finances to them in its regular financing operations. The core aspect of any IMF program, and these alike, is an implementation of a set of reforms which should improve the position of public finances and bring them back to sustained condition in medium term. 
measures, one might report the largest fragmentation in the market in 2011 and 2012 than in any other period during the last two decades.

Besides dispersion in yields, as a general but not ideal indicator of integration in government bond market belonging to the category of price-based indicators, appraisal of the degree of integration might be additionally carried out by complementary indicators. Baelle, Ferrando, Hördahl, Krylova \& Monnet (2004) proposed indicator based on the notion that yield changes in integrated market should proportionately be more driven by common news rather than local news. Conceptually, this indicator concentrates on the effects of information that has economic significance and drives bond prices. In an integrated market, the news of common or global nature should make more impact on bond prices and yields, whereas local news is to exhibit declining impact in this regard. The task to be carried out then is how to disentangle which part of yield changes is driven by common news and which by local ones. First, the choice of benchmark bond is to be done, whose yield changes should be a good proxy for correct reaction of bond prices on common news. In the 10-year government bond market, German bonds are considered as benchmark bonds. If price movement of these bonds is a reflection of true influence of common news factors, then all other bonds ' prices should presumably react in the same manner, provided that the degree of systematic risk is identical. In effect, this means that German bond yields were predominantly expected to move in accordance with common euro area news rather than local German news. Second, a regression of the changes in each country's 10 -year government bond yield $\left(\Delta R_{i, t}\right)$ on a constant and the change in the benchmark bond's yield $\left(\Delta R_{b, t}\right)$ is estimated.

$$
\Delta R_{i, t}=\alpha_{i, t}+\beta_{i, t} \Delta R_{b, t}+\varepsilon_{i, t}
$$

The estimation is carried out using a moving regression technique so as to obtain a time series of constant and estimates of slope for leading euro area countries. This makes plausible analysis of parameters' dynamics over time, which is important when considering progress in integration. A moving window is set at eighteen months. Figure 3 depicts results obtained for slope estimates $\left(\beta_{i, t}\right)$.

The value of beta coefficient equal to 1 corresponds to a situation of perfect market integration. Since estimated beta is country specific, one might infer whether integration in one country progresses or recedes. As long as the conditional beta coefficient converges to 1 , the market integration improves and vice versa, when beta coefficient diverges from 1. Figure 3 shows that betas had varied substantially in the pre-euro period, although the convergence accelerated in all countries as they approached closer to date of euro adoption. Greece has been an exception, 
which can be explained by its delay in accession to the euro area, since it joined in 2001. As of 1999 for the initial euro area members, and from 2001 for Greece, betas were virtually equal to 1 . However, the picture of an almost perfect integration came to an end in 2008. The divergence trend for beta was set in motion with betas for a few countries starting to noticeably diverge from 1. A common feature for these countries was q deteriorated fiscal position.
Figure 3: Developments of beta coefficients for government bonds with 10-year maturity

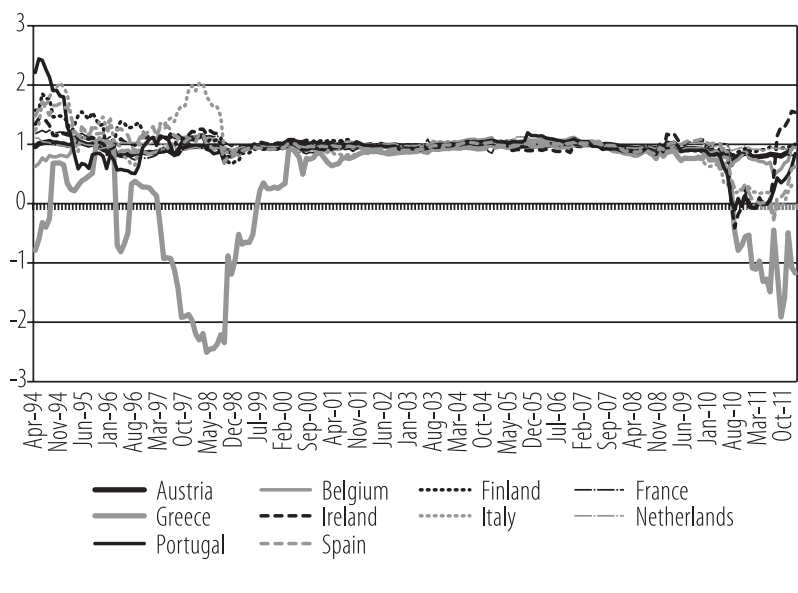

Source: Author's calculations

The closer estimated beta to null, a particular country's bond yields react weaker to changes in yield of benchmark bond. The extreme case is one in which the value of beta is negative. It is interpreted as if a fall in yield of benchmark bond is accompanied by a rise in non-benchmark country's bond yield, and vice versa. Effectively, yields move in opposite directions. These developments characterize segmented markets. Sadly, they were observed in government bond market in euro area in recent years. The results of work by Ehrmann \& Fratzscher (2015) support the main finding of above analysis on high current degree of fragmentation.

\section{Conditions in the government bond market and monetary policy}

Monetary and fiscal policies strongly interact. In normal circumstances, fiscal policy poses a challenge for monetary policy when an excessive rise in government expenditures triggers demand and inflationary pressures. Nevertheless, an excessive level of government debt may also force central bank to engage in order to preserve a smooth functioning of markets and proper transmission of monetary policy impulses. In a monetary union, setting this risk is very pronounced. National fiscal authorities share benefits of single currency and access to a large pool of savings, which constitutes incentives for excessive government borrowing. If debt can be financed at more or less equal and low union-wide determined 
interest rates, governments would run unsustainable fiscal deficits that eventually are to exert upward pressure on area-wide interest rates, thus colliding with monetary policy's objective and leading to unfavourable financing conditions for all economic agents in all participating countries.

Gonzáles-Páramo (2011) argues that three channels are set in motion when considering the impact of government bonds on monetary policy transmission. First, there is a price channel. The yield on government bonds is a floor level of interest rates which banks take into account when pricing their loans. Secondly, the balance sheet channel is relevant. Due to favourable treatment of government bonds, for example in the Basel standards inspired regulations, banks prefer to hold a sizeable portion of government bonds in their securities portfolio. Usually, they are considered safe and liquid assets. Any change in the prices of government bonds may translate into huge losses in banks' trading books. In the end, these bonds are important as they account for the prime source of collateral in interbank lending, and collateralized transactions in general. This is the liquidity channel. As banks exhibit home bias in their portfolio holdings, they are prone to holding a large proportion of domestic government bonds. This gives rise to a link between banks and sovereign funding. When domestic government bonds market is under pressure, this translates into domestic banks encountering difficulties in cross-border trading in the interbank market as counterparties are unwilling to accept respective bonds as collateral. In sum, integration of government bond market impacts the way monetary policy signals are transmitted, especially in the single currency area consisting of different countries which financial systems are bank-based. If the government bond market were disrupted, the smooth and balanced transmission of signals throughout the area might be endangered.

Historically, central banks have been paying attention to keeping close ties with governments. Apart from being the fiscal agent, they have sometimes acted as very important financiers of their respective governments, either through direct government lending or buying their securities. In the European Economic and Monetary Union (EMU), a document referred to as the Treaty on the Functioning of the European Union (TFEU) that entered into force in 2009 stipulates rules concerning monetary-fiscal policy linkage in the euro area. It rests on the following rules: a.) the prohibition of monetary financing; b.) the prohibition of privileged access to financial institutions; c.) the no-bail-out clause and d.) provisions for avoiding excessive government deficits. These rules, if followed, should ensure prudent fiscal policies. 
Goodfriend (2007) argued that the stable currency requires the independence of central bank and its commitment to price stability, and also the effectiveness of fiscal authorities to ensure sound public finances. Market discipline is an effective disciplinary device in this regard. It is defined as the pressure exerted by financial markets on governments and companies so as to pursue sound policies and sustainable finances. The mechanism of market discipline can function properly only if some preconditions are met. They are partly in parallel with provisions of the TFEU. Financial markets can only price government bonds properly if governments don't enjoy preferential access to financial opportunities, either through pressure on investors to buy these bonds or their preferential tax status. This assures a level playing field for government and private borrowing. Another precondition relates to each country's responsibility to bear complete financial consequences of default on its bonds. Market assessment of credit risk of a particular country's bonds might be blurred if there is a possibility of bailout, debt takeover or guarantee given by other party. In effect, other countries might step in and bailout country in financial difficulties, which affects the expected recovery rate in case of default. In a monetary union setting, incentives are very pronounced in favour of such interventions. In general, if the recovery rate is overestimated, the credit risk is underestimated and the respective bond is incorrectly priced. Finally, the availability of timely and accurate information on public finances is the cornerstone for market assessment of bonds' risk. Sometimes, a misreporting by national authorities conceals true fiscal developments.

An explanation for the occurrence of the sovereign debt crisis points to an ineffective market discipline since the EMU establishment. In the mid-1990s, budget balances in the EMU members ranged between a 3\% surplus and a 10\% deficit, with the debt to GDP ratios ranging from $7 \%$ to $133 \%$. Comparatively, in the mid2000 s, budget balances varied between a $2 \%$ surplus and a $5 \%$ deficit and debt to GDP ratios ranged from $7 \%$ to $108 \%$. However, in the former period, yield differentials on government bonds were substantial and often measured in hundreds of basis points, while in the latter period they rarely exceeded the limit of 20 or 30 basis points. These facts make a puzzle. An observed compression of yield differentials is mainly attributed to the elimination of exchange risk. This risk was believed to have been the major determinant of interest rates in the pre-euro period, and accordingly yield differentials. In addition, inflation risk premium in interest rates diminished as the ECB was entitled to run price stability-oriented monetary policy. The ECB provides a typical example of how a credible monetary policy can contribute to a smooth conduct of fiscal policy by delivering low inflation premium due to firmly anchored inflation expectations that is then incorporated into government bond yields. This effect was most beneficial for countries that recorded above average inflation rates in the run-up to the third stage of the EMU. 
Also, an overall compression of risk premiums on a global scale in the mid-2000s was due to a significant underpricing of risks when investors were searching for yield in the circumstances of abundant global liquidity.

The question arises whether the progress in integration of government bond markets that characterized the mid-2000s had helped improve the efficiency of financial markets in implementing market discipline or whether it has impeded it. Due to events that occurred in the following period, a small differentiation in yields appears to have resulted from market participants' misjudgements. Although yield differentials have persisted and countries with poorer fiscal positions paid higher interest rates on issued securities, that difference was too tiny to properly reflect implied risk of default. This somewhat contradicts the general attitude that elimination of barriers to trade and increased competition in the financial markets should enhance their capacity to accurately price financial assets. Another drawback of increased financial integration that came to surface in the crisis run-up was the build-up of sizeable public and private sector imbalances. Although declining interest rates helped countries to reduce the interest burden on public finances, governments have managed to accumulate growing budget deficits. In addition, the private sector has built imbalances as well. Countries with the current account deficits also characterized the increasing private sector leverage. Apart from growing leverage of non-financial corporations and households, where the latter often initiated a housing market boom, the banking sector exhibited surged leverage as well. These public and private sector imbalances aggravated countries' standing in the wake of the crisis.

The relevance of government bond market for monetary policy also follows from an adverse financial sector-fiscal policy feedback loop observed in the period of financial turmoil. In order to counteract the adverse consequences of the financial crisis, the euro area governments adopted a set of fiscal stimulus measures, including those aimed at the financial sector support. However, due to the contraction of economic activity and the size of stimulus packages, fiscal deficits and debt ratios exploded. In the period 2007-2010, the fiscal deficit for the euro area as a whole, expressed as a percentage of GDP, increased by 5.6 percentage points ${ }^{2}$, whereas the debt to GDP ratio upsurge amounted to 22 percentage points. Rapid aggravation of public finances initiated for the first time a comprehensive repricing of the euro area countries' sovereign risk in the stage three of the EMU. Market participants commenced to take heavily into account the current and prospective fiscal strengths and weaknesses. This market behaviour implies non-

2 The trend reversed in 2011-2013 period when slight improvement was observed and negative fiscal balance for the euro area as a whole shrank 1.2 percentage points. 
linearity in essence. When deficit and debt levels are relatively low, or up to a certain size, the reaction of markets is slow and weak, but when they break the threshold, markets respond quickly and abruptly.

When governments stepped in at the end of 2008 with first measures and allocated funds, they essentially transferred the risks from the financial sector to themselves. Consequently, investors started to demand lower yields on bank bonds and higher yields on government bonds. Government bond yield spreads widened as country-specific news were becoming increasingly important in determination of each country's yield ${ }^{3}$. Unfortunately, the initial risk transfer induced the second order effects once activated. Declining prices of government bonds affected the financial sector and real economy. The discussed balance sheet channel, related to the value of banks' securities portfolio, proved important in this regard. Creditworthiness of banks was again impaired converting into a rise of their funding costs, especially when considering market-based funding. The downward spiral was not stopped. Weakened balance sheets of banks and issues with funding induced them to cut lending and tighten credit standards. Finally, negative effects of disrupted lending to the economy stroke forcefully sovereigns' financial standing. Public finances were again under strains and adverse feedback loop was completed. In the acute period of crisis, one consideration was important too - possibility of contagion in government bond markets. If one euro area country was exposed to severely deteriorated fiscal situation and had its interest rate raised, this could spill over to interest rates paid by other euro area countries. The rise in bond yields of some countries whose fundamentals had not changed at least partly was attributed to side effects of another country's financial difficulties. The risk of contagion proved influential in 2011. While only bond yields of Greece, Ireland and Portugal were strongly affected in 2010 due to market revaluations of the countries' fiscal positions, in 2011, bond yields of other countries were exposed to upward pressure and rose as well.

The implications and facts discussed above formed a strong motivation for the ECB to act and try to mitigate adverse repercussions of financial instability and sovereign debt crisis. Its main policy measures are considered in the next section.

3 This was also confirmed by developments in the credit default swap market where CDS spreads of the euro area countries rose markedly. Sovereign yield differentials appeared to be governed by developments in the CDS spreads. 


\section{Central bank and sovereign debt crisis}

Initial interest of the ECB to intervene in the wake of the global financial crisis was related to euro area money market tensions. In order to prevent the freezing of interbank money market, the ECB opted for liquidity provision measures that would relieve solvent banks from unduly liquidity problems, and ultimately enable free flow of credit to firms and households. However in 2010 crisis resurged in the form of sovereign debt crisis, and this time it was a genuine European crisis.

Sovereign debt market is manifold important for monetary policy, as pointed above. Yet, the ECB in the EMU stage three has never intervened in this market for more than a decade. The main reason being that the market proved highly integrated and smoothly operated with artificially low yield spreads. Furthermore, the monetary financing prohibition rule added to reluctance of the ECB to buy government bonds, and also its monetary policy operational framework rested on main refinancing operations that were executed through transactions with credit institutions and aimed at steering money market conditions. Figure 4 depicts the structure of general government debt according to the type of its holder in the last quarter of 2008. It confirms marginal holding of government debt by national central banks of the euro area, if at all. Also, large foreign hold-

Figure 4: Breakdown of general government debt in $\mathbf{2 0 0 8}$ per type of holder

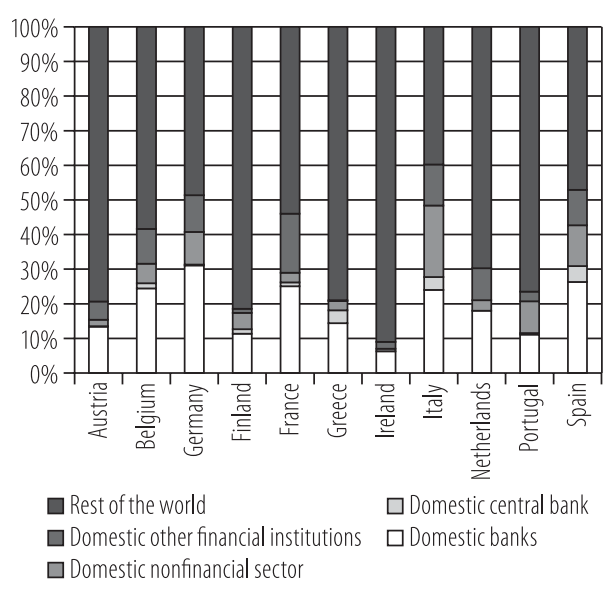

Source: ECB and national central banks of euro area countries ings of government debt (tagged Rest of the world in Figure 4) are observed for Ireland, Greece, Finland, Portugal, Austria and Netherlands. Domestic non-financial sector is an important holder of debt only in Italy, and to a somewhat lesser extent in Spain, Portugal, and Germany. When it comes to domestic banks' holding, Germany stands out. A more detailed analysis of foreign debt holders reveals additional insights. Foreign central banks were large holders of debt for Germany, France, Netherlands, and Finland. Interestingly, their share was negligible for Greece and Italy. Foreign commercial banks were important holders in every country, with largest shares of around 20\% in Greece and Portugal. However, the predominant holders of debt in these two countries and Aus- 
tria were foreign other financial institutions and the non-financial sector.

Figure 5 displays the same data as in Figure 4, but as of last quarter 2014. As expected, as German government bonds were the main target of "flight to quality" behaviour of market participants during the crisis, when investors searched for safe heaven assets, the share of foreign holdings increased. The same behaviour, but with smaller magnitude, was observed in France as well. On the opposite side, the Netherlands has seen the biggest retrieval of foreign investors in its government bonds, with all other countries following the same pattern. As a matter of fact, Ireland has recorded the largest drop in foreign holdings, but it stemmed from its intense stress. Actually, the main change in the structure of holders refers to the composition of foreign holders. New categories of holders appeared - the EU, the IMF, and the ECB. A joint collaboration of these three institutions in addressing problems of distressed countries and granting financial assistance to them is often referred to as Troika program. Moreover, the ECB developed its independent programmes for the acquisition of government bonds. Greece, Ireland and Portugal concluded negotiations with Troika and drew upon available funds. In relative terms, Troika bailout funds are the most important for the Greek public finances where they account for more than $60 \%$ of the outstanding government debt. For Ireland and Portugal, the stakes of Troika held government debt are about equal and amount to roughly one third of total debt.

The ECB introduced three programmes involving sovereign bond purchases in the course of time: 1) Securities Markets Programme (SMP), 2) Outright Monetary Transactions (OMTs) and 3) Public Sector Purchase Programme (PSPP). Initially, the recognition of the ECB in 2010 that market tensions had spilled over from sovereign market to money market prompted it to opt for unprecedented measures. At the time, the cross-country deviation of the EONIA rate abruptly rose to levels higher than those observed at the peak of the global financial crisis in 2009. As a response, the ECB launched the SMP in May 2010. The SMP allowed 
the ECB to buy both private and sovereign bonds, although the emphasis was on the latter and the former have not been bought at all. In the first round of purchases, only the bonds of Greece, Portugal, and Ireland were included in the total amount of 75 billion euros; while Italian and Spanish bonds entered the second round in 2011 when total holdings surged to close to 220 billion euros. Distribution of the holdings by the country as of December 2012 is given in Table 4.

Table 4: Breakdown of the ECB's SMP holdings per country of issuer

\begin{tabular}{lcc}
\hline Country & $\begin{array}{c}\text { Outstanding amount } \\
\text { (in billions } € \text { ) }\end{array}$ & $\begin{array}{c}\text { Average remaining maturity } \\
\text { (in years) }\end{array}$ \\
\hline Ireland & 14,2 & 4,6 \\
\hline Greece & 33,9 & 3,6 \\
\hline Spain & 44,3 & 4,1 \\
\hline Italy & 102,8 & 4,5 \\
\hline Portugal & 22,8 & 3,9 \\
\hline Total & 218 & 4,3 \\
\hline
\end{tabular}

Source: $E C B$

The SMP was special in many regards. All purchases under the SMP were performed on the secondary market. It is in line with theoretical recommendations, the Federal Reserves' (FED) practice and the EU's monetary financing prohibition. However, every purchase was a one-off measure in the sense that the ECB did not intend to sell these bonds later but rather hold them until maturity. Correspondingly, any decrease in the size of the SMP portfolio was attributed to redemption of bonds bought. By its nature, the SMP might be assessed as opaque. The ECB did not share with the public in advance any information on planned purchases of bonds. The information on total amounts bought, specific securities purchased or duration of programme have not been released either. The structure of the SMP portfolio was disclosed only when it had become terminated. As a result, the markets knew rather little about SMP transactions. In effect, every purchase of bonds came as a surprise. This is in a stark contrast with bond purchase programmes implemented by other central banks, such as the FED or the Bank of England $(\mathrm{BoE})^{4}$, where the level of transparency was high and auctions pre-announcements common. Purchases of bonds through SMP were concentrated in time and mainly took place in weeks of severe stress, while FED and BoE spread their purchases over much longer time horizon and more evenly.

\footnotetext{
4 A good overview of leading worldwide central banks' asset purchases programmes is provided in Fawley \& Neely (2013).
} 
A distinctive feature of SMP, compared to the FED or the BoE programmes, was related to the primary purpose of intervention. The objective of SMP was to ensure depth and liquidity in those market segments which were dysfunctional and to restore an appropriate monetary policy transmission mechanism. Strictly speaking, SMP transactions were not intended to influence monetary policy stance. Consequently, they were not to be taken as a quantitative easing measure, which was the focal point of similar FED and BoE programmes. A quantitative easing is aimed at complementing monetary policy stance once the main policy rate has reached a lower bound, effectively zero. In order to convince the public that no monetary accommodation was taking place, the ECB announced a plan to drain liquidity injected in the system through SMP transactions mainly by weekly operations of auctioning fixed term deposits. It meant that banks were invited to deposit a certain amount of money for a period of one week, deposits being interest-bearing. Belke (2010) was the greatest critic of SMP on the ground of monetary policy stance implication. Accidentally or not, the ECB suspended liquidity-absorbing operations in June 2014 and left SMP transaction effects unsterilized. Furthermore, it turned out that the ECB more often failed than succeeded to neutralize effects of SMP transactions since banks had rarely offered deposits in size equal to SMP portfolio but rather fell short. The SMP alone was terminated in September 2012 and no additional purchases have been made ever since. As of June 2015, the size of the SMP portfolio has fallen to 130 billion euros.

Krishnamurthy, Nagel \& Vissing-Jirgensen (2014) curiously argue that two 3-year Long-Term Refinancing Operations (LTRO) were intended, inter alia, to support sovereign debt market. The support is rather indirect and based on assumption that banks would purchase sovereign bonds using LTRO money. Anecdotal evidence confirms this assumption since banks disproportionately increased bond holdings around the time LTRO-s were conducted, at the end of 2011 and the beginning of 2012. However, these purchases were characterized by home bias since resident banks prevailed as buyers of sovereign debt, rather than non-resident banks. Authors further found the ECB policies involving government bond purchases to be successful in reducing sovereign bond yields, with beneficial macroeconomic spillovers raising, inter alia, the stock prices.

A bulk of authors tried to assess direct effects of the ECB's government bond purchases recently. They predominantly concentrated on yields changes. Eser \& Schwaab (2015) found an average impact at the five year maturity per 1 billion euros of bond purchases spanning from -1 to -2 basis points for Italy, to -17 to -21 basis points for Greece, with the rest of distressed countries falling somewhere in between. They attributed cross-country differences to different sizes of the respective markets and a default risk signal. De Pooter, Martin \& Pruitt 
(2012) focused on sovereign markets functioning and liquidity implications of the SMP. They argue that the ECB provided a reliable source of demand for sovereign bonds of distressed countries, and consequently allowed investors to take larger positions in these bonds with a final thought of being able to sell them to the ECB if needed. In turn, this drives the liquidity risk premium embedded in yields down. The authors' empirical estimates suggest significant temporary and lasting decreases in liquidity premium. Trebesch \& Zettelmeyer (2014) dealt exclusively with the SMP impact on Greek bonds. They assert the ECB`s favoured large benchmark bonds with a remaining maturity of less than 10 years with comparatively high yields. Based on obtained results, they estimated that the total decline in yields attributable to the ECB purchases had been between 180 and 200 basis points. Also, due to its volume, the ECB purchases were accompanied by the Greek yield curve turning from downward sloping to normal upward sloping in a matter of days following interventions. Most recently, De Pooter, DeSimone, Martin \& Pruit (2015) focused on the overall yield impact. They concluded that the ECB's SMP had influenced yields more through a confidence channel than by the means of direct purchases. The efficacy of the SMP appears not to have arisen from the size and timing of the purchases but rather from communications and prevailing market beliefs. The ECB's announcements appeared to have a substantial effect, and SMP as a whole proved successful in lowering peripheral countries' yields and spreads.

The successor of the SMP is Outright Monetary Transactions (OMTs) programme introduced in September 2012. The SMP was put in place as a quick ECB response to strains in sovereign debt markets of three peripheral euro area countries with the aim to restore the monetary transmission mechanism within the euro area. The size of interventions was at the time deemed small enough so as purchases needed might have been carried out without any distortion in the conduct of monetary policy. Luckily, with Italy and Spain confronting market pressures in the summer of 2012 ECB had ready answer in the form of SMP, but the increase in the respective portfolio threatened to undermine ECB's standing and credibility. The new programme needed to be devised to address widened sovereign debt crisis on a more firm ground and in a comprehensive manner. OMTs envisaged purchases of sovereign debt in the secondary market, with priority given to maturities between 1 and 3 years and without any quantitative limit. On the opposite side, conditionality has been introduced, an important feature the SMP lacked. As of September 2012, any euro area country wishing the ECB to buy its bonds should first negotiate a macroeconomic adjustment programme within the European Stability Mechanism (ESM) framework and abide to the agreed conditions. Since the ESM is a permanent crisis management mechanism already providing financial assistance to countries in need, the ECB's OMT's might be 
regarded as an additional guarantee that particular countries would receive the requested aid. At present, only Cyprus fulfils the criteria for OMTs. In addition, to date, no purchases have been carried out under the OMTs and subsequent programme results are impossible to comment. Nevertheless, De Pooter et al. (2015) stated that a mere announcement of OMTs initiated a decline in yields.

OMTs have attracted much attention and inspired controversy. The German Constitutional Court even asked the European Court of Justice (ECJ) to rule on whether OMTs fell within the ECB` mandate and were they compatible with EU law. In June 2015, the ECJ announced its ruling according to which OMTs did not exceed the powers of the ECB in relation to monetary policy. If the ECJ had made different ruling, it would have meant the cancelation of all prospective purchases of the euro area sovereign bonds and would tie the ECB's hands with regard to addressing the sovereign debt crisis.

Finally, starting from January 2015, the ECB opened a new chapter in its asset purchase endeavours. A fresh programme named the Expanded Asset Purchase Programme (EAPP) was set in motion. Having in mind a prolonged period of low inflation, the ECB embarked upon EAPP which in many regards replicates programmes implemented by other leading central banks in advanced economies. While previous ECB`s programmes were implemented in a setting characterized by fear of inflation, the current programme is spurred by deflation considerations. The EAPP envisages: 1) purchases of both public and private sector securities, 2) combined monthly asset purchases equal to 60 billion euros, and 3) continuation of purchases at least until September 2016. According to expectations, the accompanying expansion of monetary base should reverse the trend in price developments, help the ECB meet the inflation target, and lead to rising inflation expectations. Monetary stimulus is also expected to support investment and consumption by making the access to finance cheaper.

In quantitative terms, the focal part of the EAPP refers to the Public Sector Purchase Programme (PSPP). It became fully functional in March 2015 when first transactions were carried out. The PSPP operates in a decentralized manner. The ECB coordinates all purchases, and directly buys and holds only $8 \%$ of the total amount, whereas the remaining $92 \%$ is to be covered by national central banks (NCBs) of the euro area. In that sense, the PSP is more of a Eurosystem's programme than exclusively of the ECB. Strict limits are set in order to preserve normal secondary market functioning, with 25\% security-specific limit and 33\% issuer-specific limit. Intended purchases are carried out across euro area jurisdictions according to the ECB's capital key. The general allocation scheme predicts a share of government bonds and recognized agencies bonds; and securities issued 
by international organisations and multilateral development banks to account for $88 \%$ and $12 \%$ in the total amount, respectively. The ECB is allowed to purchase solely government bonds and bonds of recognized agencies. NCBs are allowed to buy government bonds and recognized agencies of their own jurisdiction, for instance Bundesbank will restrict purchases to German government bonds and bonds of recognized agencies incorporated in Germany. Any loss occurring from holdings of government bonds is not subject to loss sharing across the Eurosystem. This rule makes individual government default risk ring-fenced. A preliminary breakdown of debt securities held under PSPP across jurisdictions is given in Table 5.

Table 5: Breakdown of debt securities under the PSPP per NCB's holdings

\begin{tabular}{l|ccccc}
\hline Country & 31.3 .2015 & 30.4 .2015 & 31.5 .2015 & 30.6 .2015 & 31.7 .2015 \\
\hline Austria & 1216 & 1205 & 1314 & 1310 & 1363 \\
\hline Belgium & 1528 & 1530 & 1656 & 1657 & 1642 \\
\hline Cyprus & & & & & 98 \\
\hline Germany & 11070 & 11148 & 12144 & 11970 & 11975 \\
\hline Estonia & 0 & 0 & 0 & 5 & 15 \\
\hline Spain & 5447 & 5471 & 5909 & 5915 & 5891 \\
\hline Finland & 774 & 786 & 841 & 836 & 850 \\
\hline France & 8757 & 8624 & 9485 & 9426 & 9465 \\
\hline Ireland & 722 & 735 & 775 & 784 & 771 \\
\hline Italy & 7609 & 7585 & 8228 & 8164 & 8248 \\
\hline Lithuania & 39 & 83 & 123 & 133 & 126 \\
\hline Luxembourg & 183 & 205 & 84 & 261 & 80 \\
\hline Latvia & 75 & 177 & 205 & 46 & 22 \\
\hline Malta & 5 & 53 & 85 & 66 & 24 \\
\hline the Netherlands & 2487 & 2527 & 2667 & 2663 & 2657 \\
\hline Portugal & 1074 & 1084 & 1174 & 1164 & 1160 \\
\hline Slovenia & 209 & 219 & 231 & 228 & 232 \\
\hline Slovakia & 506 & 522 & 529 & 546 & 442 \\
\hline Supranationals & 5682 & 5748 & 6173 & 6267 & 6300 \\
\hline Total & 47383 & 47701 & 51622 & 51442 & 51359 \\
\hline
\end{tabular}

Source: ECB

The PSPP does not represent a programme addressing the sovereign debt crisis issue. In essence, it is a genuine monetary policy tool. It matches all requirements of a quantitative easing doctrine. Alike providing abundant liquidity to banks 
through refinancing operations in the wake of crisis, the PSPP will inflate ECB and NBCs balance sheets. The balance sheet composition will change as well. The monetary policy will be somewhat more national, due to the power given to buy local bonds. The losses will overwhelmingly stay within borders too, with one exception. The Governing Council of the ECB decided that purchases of securities of European institutions are to be subject to loss sharing if it materializes, no matter which NCB bought them. If one adds $12 \%$ of purchases directed into these securities and $8 \%$ of total amount bought by the ECB, it turns out that $20 \%$ of total exposures through the PSPP are subject to the risk sharing regime. Most importantly, the PSPP enables equal footing for different government bonds of the euro area countries. With this programme the ECB has entered into new phase of implementing monetary policy and accomplishing its target.

\section{Conclusion}

The sovereign securities market in Europe has undergone a period of dynamic development and profound changes in the past fifteen years. Initially, the market had grown strongly, its liquidity had improved, and new instruments were launched so government bonds of different countries have become close substitutes in the perception of investors. In the euro area, government bond yields converged and overall integration of the market was rather high and presented one of the most integrated financial market segments. Low yield spreads were furthermore accompanied by clear signs of co-movement in bond yields, pointing to comprehensive integration. At the end of 2008, dramatic shift occurred and ever since disintegrative forces have been in motion. Dispersion in bond yields rose, with the euro area countries experiencing unfavourable fiscal developments as the hardest setback. The paper presented the following measures of integration of the government bond markets: yield spreads, dispersion in yield spreads, and beta coefficient. All three measures suggest unprecedented market disintegration as of 2010. The magnitude of yield spreads and beta coefficients points at the position of individual countries, and serves as a criterion for subsequent grouping of countries. At present, the euro area countries segregate in two groups: a) distressed countries and b) non-distressed countries. The second group had recently regained some of the integration achieved in the pre-crisis period to lose it afterwards. Conclusively, yield spreads are not expected to return to the pre-crisis levels in the near future since market forces now more cautiously price credit risk of sovereigns and liquidity risk of particular sovereign security.

Following the notion that exceptional times may require exceptional policy measures, the ECB has taken on an unusual set of measures in coping with ad- 
verse crisis effects. While the first round consequences of the global financial crisis were addressed by one set of measures, the second round effects of sovereign debt crisis needed to be resolved with a different package of measures. The paper highlighted the relevance of the sovereign bond market for smooth functioning of the monetary policy transmission mechanism in a monetary union context. In essence, funding strains of individual governments translate into funding and solvency problems for resident banks. The crisis spills over from the sovereign debt market to the money market, bringing the effective transmission of monetary policy to a halt because in the last instance divergence in the cost and availability of resident banking sector funding translates into the divergence in the cost and availability of external financing to the non-financial private sector. A withdrawal of foreign private investors in distressed countries' bonds is confirmed by elaborating changes in bond holdings. Instead, the ECB has become an important holder together with the IMF and the EU. Three ECB's programmes aimed at sovereign debt crisis resolution were analysed in details. The SMP is perceived as a rescue programme for three peripheral euro area countries. The SMP as a whole proved successful in lowering peripheral countries' yields and spreads. OMT is more perceived as the ECB's firm commitment rather than a programme involving real purchases of bonds. Nevertheless, it proved effective in calming the markets. If one takes a central bank function of the lender of last resort, than OMT may be viewed as the "buyer of last resort" device for government bonds. The PSPP is an entirely different programme more directly related to the ECB's mandate. It has been launched recently and any assessment of its results would be premature. Although promoted as a genuine quantitative easing programme, it might be argued that it is indirectly backing the EU wide financial support to distressed countries. In one sense, it facilitates a smooth transfer of funds from budgets of individual euro area countries to the EU financial facilities deployed for distressed countries. When the ECB buys outstanding government bonds, remaining demand for bonds is directed to the primary market, so any country wishing to issue additional bonds is to expect a successful sale of new issues and, if needed, transfer the proceeds to the EU facilities. The more successful the reform and consequent implementation of mechanisms for ensuring sound public finances, the more likely is the withdrawal of non-standard measures related to the government bond market and relief of monetary policy from having to address negative externalities from the fiscal policy area. It is important since nonconventional programmes pose certain challenges for monetary policy conduct and might even have unintended consequences. 


\section{References:}

1. Abad, P., Chulia H. \& Gomez-Puig M. (2009). EMU and European Government Bond Market Integration, European Central Bank, Working Paper Series No.1079.

2. Baele, L., Fernando, A., Hördhal, P., Krylova, E. \& Monnet C. (2004). Measuring Financial Integration in the Euro Area, European Central bank, Occasional Paper Series No. 14.

3. Becker, S. (2009). EMU sovereign spread widening, Deutsche Bank Research, EU Monitor 68.

4. Belke, A. (2010). Driven by the Markets? ECB Sovereign Bond Purchases and the Securities Markets Programme, Intereconomics, 6(2010), 357-363.

5. Benoît, C. (2015, March 10). Embarking on public sector asset purchases. Speech at the Second International Conference on Sovereign Bond Markets, Frankfurt. Retrieved from: https://www.ecb.europa.eu/press/key/date/2015/ html/sp150310_1.en.html.

6. Blundell-Wignall, A. \& Patrick S. (2010). A Market Perspective on the European Sovereign Debt and Banking Crisis. OECD Journal: Financial Market, 2(2010), 1-28.

7. Curdia, V. \& Woodford, M. (2011). The central-bank balance sheet as an instrument of monetary policy. Journal of Monetary Economics, 1(58). 54-79.

8. D’Amico, S., English, W., López-Salido, D. \& Nelson., E. (2012). The Federal Reserve's Large-scale Asset Purchase Programmes: Rationale and Effects. The Economic Journal, 564 (122): 415-446.

9. De Haan, J., Oosterloo S. \& Schoenmaker D. (2009). European Financial Markets and Institutions. Cambridge: Cambridge University Press.

10. De Pooter, M., DeSimone, R., Martin, R. \& Pruit, S. (2015), Cheap Talk and the Efficacy of the ECB`s Securities Markets Programme: Did Bond Purchases Matter? Federal Reserve Board of Governors, International Finance Discussion Papers No. 1139.

11. De Pooter, M., Martin, R. \& Pruitt S. (2012). The effects of official bond market intervention in Europe. Federal Reserve Board of Governors, Working Paper.

12. Economic and Financial Committee. (2000). Progress Report on EU government Bond instruments. Brussels: EFC.

13. Ehrmann, M. \& Fratzscher M. (2015). Euro Area Government Bonds Integration and Fragmentation During the Sovereign Debt Crisis, Centre for Economic Policy Research, Discussion Paper No. 10583.

14. Eser, F. \& Schwaab, B. (2015). Evaluating the impact of unconventional monetary policy measures: Empirical evidence from the ECB's Securities 
Markets Programme. Journal of Financial Economics, Accepted Manuscript, doi:10.1016/j.jfineco.2015.06.003.

15. European Central Bank (2006). Fiscal Policies and Financial Markets. Monthly Bulletin, February 2006.

16. European Central Bank (2012). Monetary and Fiscal Policy Interactions in a Monetary Union. Monthly Bulletin, July 2012.

17. European Central Bank. (2004). The Euro Bond Market Study. Frankfurt am Main: ECB.

18. European Central Bank. (2007). The Euro Bonds and Derivatives Markets. Frankfurt am Main: ECB.

19. European Central Bank. (2010). Financial Stability Review, December 2010. Frankfurt am Main: ECB.

20. European Central Bank. (2011). Financial Stability Review, December 2011. Frankfurt am Main: ECB.

21. European Central Bank. (2013). Financial Integration in Europe. Frankfurt am Main: ECB.

22. Fawley, B. \& Neely, C. (2013). Four Stories of Quantitative Easing. Federal Reserve Bank of St. Louis Review, 1(95), 51-88.

23. Fitch. (2012, August 24). Sovereign Rating History. Retrieved from: https:// www.fitchratings.com/web.../ratings/sovereign_ratings_history.xls

24. Gonzáles-Páramo, J.-M. (2011, October 21). The ECB`s monetary policy during the crisis. Closing speech at the Tenth Economic Policy Conference, Malaga. Retrieved from: https://www.ecb.europa.eu/press/key/date/2011/ html/sp111021_1.en.html

25. Goodfriend, M. (2007). How the World Achieved Consensus on Monetary Policy. Journal of Economic Perspectives, 4(21), 47-68.

26. Krishnamurthy, A. \& Vissing-Jorgensen, A. (2011). The Effects of Quantitative Easing on Interest Rates: Channels and Implications for Policy. Brookings Papers on Economic Activity, 2(43). 215-265.

27. Krishnamurthy, A., Nagel, S. \& Vissing-Jirgensen A. (2014, August 14). ECB Policies involving Government Bond Purchases: Impact and Channels. Retrieved from: http://eml.berkeley.edu// webfac/gourinchas/ECBPolicies. pdf

28. Lukić, V. (2012). "Monetarna politika u kriznim vremenima: Ključni izazovi i (ne)jedinstven odgovor na njih", In Zbornik radova sa naučne konferencije "Privreda Srbije u drugom talasu krize: Izgledi za 2012.", Naučno društvo ekonomista i Ekonomski fakultet u Beogradu, 255-276, Beograd: EKOF.

29. Moody's. (2010). Sovereign Default and Recovery Rates, 1983-2010. New York: Moody's.

30. Pagano, M. \& Thadden, E.-L. (2008). “The European Bond Markets under EMU”, In Handbook of European Financial Markets and Institutions, ed. 
Xavier Freixas, Philipp Hartmann and Colin Mayer, 488-518. Oxford: Oxford University Press.

31. Santillan, J., Bayle, M. \& Thygesen, C. (2000). The Impact of the Euro on Money and Bond Markets. European Central Bank, Occasional Paper Series No.1.

32. Trebesch, C. \& Zettelmeyer, J. (2014). ECB Interventions in Distressed Sovereign Debt Markets: The Case of Greek Bonds, Center for Economic Studies \& Ifo Institute, Working Paper No. 4731. 